\title{
Single nucleotide polymorphisms in breast cancer susceptibility gene 1 are associated with susceptibility to lung cancer
}

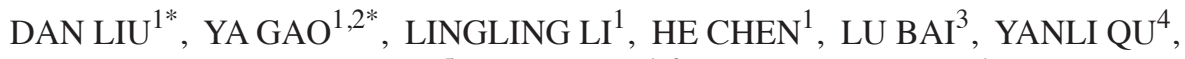 \\ BAOSEN ZHOU $^{5}$, YING YAN ${ }^{1,6}$ and YUXIA ZHAO ${ }^{1}$ \\ ${ }^{1}$ Department of Radiation Oncology, The Fourth Affiliated Hospital of China Medical University, Shenyang, Liaoning 110032; \\ ${ }^{2}$ Department of Oncology, Kailuan Hospital, Tangshan, Hebei 063000; ${ }^{3}$ Department of Radiation Oncology, \\ The First Affiliated Hospital of China Medical University, Shenyang, Liaoning 110001; ${ }^{4}$ Department of Radiation Oncology, \\ Cancer Hospital of China Medical University, Liaoning Cancer Hospital and Institute, Shenyang, Liaoning 110042; \\ ${ }^{5}$ Department of Epidemiology, China Medical University, Shenyang, Liaoning 110001; ${ }^{6}$ Department of Radiation Oncology, \\ The General Hospital of Shenyang Military Region, Shenyang, Liaoning 110016, P.R. China
}

Received March 10, 2020; Accepted February 10, 2021

DOI: $10.3892 / \mathrm{ol} .2021 .12685$

\begin{abstract}
BRCA1 is a tumor suppressor that has been found to be involved DNA synthesis during cell replication. In a recent study, the single nucleotide polymorphism (SNP), rs799917, in BRCA1 was found to be associated with the development and progression of various types of tumor. In the present study, the association between rs799917 and susceptibility to lung cancer was evaluated in a Han Chinese population in the Liaoning Province of China. The BRCA1 rs799917 genotypes (C/C, C/T and $\mathrm{T} / \mathrm{T}$ ) were analyzed using TaqMan quantitative PCR in 682 patients with lung cancer and 694 healthy controls, and the results were analyzed using a Student's t-test, a $\chi^{2}$ test and logistic regression analysis. Individuals carrying the $\mathrm{C} / \mathrm{T}$ or $\mathrm{T} / \mathrm{T}$ genotype had a lower risk of lung cancer compared with those carrying the $\mathrm{C} / \mathrm{C}$ genotype [odds ratio $(\mathrm{OR}), 0.741 ; \mathrm{P}=0.021$; and OR, 0.610; $\mathrm{P}=0.011$, respectively). The $\mathrm{C} / \mathrm{T}+\mathrm{T} / \mathrm{T}$ genotype group had an even lower risk (OR, 0.709; $\mathrm{P}=0.005)$ compared with that in the $\mathrm{C} / \mathrm{C}$ genotype group. In the stratified analyses of non-smokers, individuals with the $\mathrm{C} / \mathrm{T}$ or $\mathrm{T} / \mathrm{T}$ genotype had a lower risk of developing lung cancer compared with that in those carrying the $\mathrm{C} / \mathrm{C}$ genotype $(\mathrm{OR}, 0.681 ; \mathrm{P}=0.013$; and $\mathrm{OR}$, $0.569 ; \mathrm{P}=0.021$, respectively). The stratified analyses of the BRCA1 rs799917 polymorphism based on pathological type,
\end{abstract}

Correspondence to: Professor Yuxia Zhao or Professor Ying Yan, Department of Radiation Oncology, The Fourth Affiliated Hospital of China Medical University, 4 Chongshan East Road, Huanggu, Shenyang, Liaoning 110032, P.R. China

E-mail: zyx_yd@163.com

E-mail: yanyingdoctor@sina.com

${ }^{*}$ Contributed equally

Key words: genes, BRCA1, lung cancer, single nucleotide polymorphism chemotherapy and radiotherapy, showed that in the squamous cell carcinoma, non-chemotherapy and non-radiotherapy subgroups, individuals with the T/T genotype had a lower risk of lung cancer compared with that in those carrying the $\mathrm{C} / \mathrm{C}$ genotype (OR, 0.454; $\mathrm{P}=0.007$; $\mathrm{OR}, 0.485 ; \mathrm{P}=0.002$; and $\mathrm{OR}$, $0.599 ; \mathrm{P}=0.020$, respectively). In conclusion, the $\mathrm{T}$ allele of the rs799917 SNP in BRCA1 was associated with a lower risk of lung cancer in the ethnic Han Chinese population in Liaoning Province and may represent a protective factor against lung cancer.

\section{Introduction}

Global cancer statistics 2020 show that among malignant tumors, lung cancer has high incidence (11.4\%) and mortality rates (18\%) (1). Smoking and air pollution are important factors contributing to lung cancer based on epidemiological study results $(2,3)$. Due to individual differences, susceptibility to tobacco and carcinogens differs; therefore, predisposition to lung cancer varies. Susceptibility to this disease may be partly genetic and associated with single nucleotide polymorphisms (SNPs). This is particularly apparent with respect to the relationship between lung cancer genetic susceptibility genes and gene-related repair of DNA damage, such as ERCC1, ERCC2, XPA and XRCC1 (4).

BRCA1 is located on the long arm of chromosome 17 and encodes an 1,863-amino-acid protein involved in DNA repair and maintenance integrity of the human genome (5). The human BRCA1 gene (Gene ID, 672) is $81.2 \mathrm{~kb}$ in length and located on chromosome 17. The gene consists of 22 coding exons and transcriptionally forms a 5.7-kb mRNA, including the differentially methylated regions and the promoter region (6). The 1,000 Genomes Project has established the most detailed catalogue of mutations in the human genome, with a frequency of BRCA1 mutations of $>1 \%$ in the population based on DNA sequence variation (7). BRCA1 is a nuclear phosphoprotein, consisting of three major domains, including ubiquitin ligase, nuclear localization signal and BRCA1 Carboxy-terminal 
domains; as a tumor suppressor, it has been associated with cell migration (8-10). In human cells, this protein can interact with DNA damage-sensing proteins, DNA damage response effectors, proteins involved in centrosome replication, cell cycle regulators and other proteins, such as 53BP1, $\operatorname{Rad} 50$, c-Myc, nuclear localization sequences and PALB2 (11-15). Taken together, this information not only establishes a critical biological role for BRCA1 as a custodian of chromosome integrity during the cell cycle, but also implies the possibility that pathogenic mutations inactivating the BRCA genes could be linked to cancer susceptibility by inducing chromosomal instability and mutagenesis $(16,17)$.

Therefore, the aim of the present study was to determine whether SNPs within BRCA1 might be associated with lung cancer susceptibility. In previous reports, the BRCA1 rs799917 SNP was associated with breast cancer susceptibility (18). However, the rs799917 SNP has not been investigated in patients with lung cancer in China. Thus, a case-control study was conducted in a Han Chinese cohort from the Liaoning Province in China in order to investigate the association between the BRCA1 rs799917 SNP and susceptibility to lung cancer, thus identifying potential genetic causes and providing a scientific basis for primary prevention.

\section{Materials and methods}

Study participants. At the start of the study, a total of 2,100 patients were enrolled, including patients with pathological diagnosis of lung cancer (case group) and healthy controls (control group). The following exclusion criteria were used in the case group: i) A history of lung cancer, ii) a history of other concomitant tumors, iii) any cancer-related metastasis, iv) previous chemotherapy or radiotherapy and v) non-autologous transfusion. All patients with lung cancer were histopathologically diagnosed using the TNM staging system (19) with either squamous cell carcinoma (SCC), adenocarcinoma (AD) or small cell lung cancer (SCLC), and were from the Han population in Liaoning Province (China), without any kinship to each other. All clinical data used in the study had to be complete; therefore, 1,376 samples were excluded, due to incomplete clinical data and deficient DNA samples. Thus, a total of 682 patients with lung cancer were recruited from three hospitals: The Department of Radiotherapy from the First Affiliated Hospital of China Medical University (Liaoning, China), The General Hospital of Shenyang Military Region of Liaoning Province (Liaoning, China) and The Liaoning Cancer Hospital (Liaoning, China), between March 2010 and December 2012. A total of 694 healthy controls were randomly selected from the health examination center of The General Hospital of Shenyang Military Region during the same period. The inclusion criteria included: i) Non-basic diseases; ii) no history of tumor; and iii) voluntary participation. The exclusion criteria included: i) Family history of tumors; and ii) non-autologous transfusion. Relevant information was collected using structured questionnaires. Smoking was defined as $\geq 1$ cigarette/day for 6 months continuously or cumulatively over a lifetime (20).

SNP selection and genotyping. The NCBI database (https://www.ncbi.nlm.nih.gov/) was searched for the association between rs799917 SNP and lung cancer, and no relevant data was found. Therefore, the rs799917 SNP was selected, since it had not been previously investigated in patients with lung cancer.

A blood sample $(\sim 5 \mathrm{ml})$ was collected from each participant, then DNA was extracted using standardized protease $\mathrm{K}$ digestion, phenol-chloroform extraction and ethanol precipitation. The genotypes of the BRCA1 rs799917 SNP were determined using TaqMan quantitative PCR (Applied Biosystems; Thermo Fisher Scientific, Inc.). The TaqMan universal PCR master mix and predesigned SNP genotyping assay mix, containing PCR primers and probes, were purchased from Applied Biosystems (Thermo Fisher Scientific, Inc.). Genotyping was performed using pre-designed TaqMan probes. The specific amplicon context sequence was TTCTGCATTTCCTGGATTTGAAAAC [A/G] GAGCAA ATGACTGGCGCTTTGAAAC. The PCR reaction mixture (5 $\mu \mathrm{l})$ consisted of $1 \mu \mathrm{l}$ DNA sample (>20 ng/ $\mu \mathrm{l}), 2.5 \mu \mathrm{l}$ master mix, $0.125 \mu \mathrm{l}$ probe and $1.375 \mu \mathrm{l}$ sterile water. The PCR conditions included initial denaturation at $95^{\circ} \mathrm{C}$ for $10 \mathrm{~min}$, followed by 47 cycles at $92^{\circ} \mathrm{C}$ for $30 \mathrm{sec}, 60^{\circ} \mathrm{C}$ for $60 \mathrm{sec}$ and final extension at $60^{\circ} \mathrm{C}$ for $60 \mathrm{sec}$. The PCR plates were read on a PRISM 7900 instrument (Applied Biosystems; Thermo Fisher Scientific, Inc.). Deionized water was used as a negative control and the rs3219073/GG SNP of poly(ADP-ribose)polymerase 1 (PARP-1) was used as a positive control, since it has been previously detected in numerous lung cancer samples (21). The $2^{-\Delta \Delta \mathrm{Cq}}$ method was used for quantification (22). A double-blind repeat test was performed on randomly selected samples $(10 \%)$ to verify the results.

Statistical analysis. SPSS version 17.0 (SPSS, Inc.) was used for statistical analysis. Parametric continuous variables are presented as the mean \pm SD and compared using an unpaired Student's t-test. The clinicopathological differences between patients with lung cancer and healthy controls were assessed using a $\chi^{2}$ test, while the goodness-of-fit $\chi^{2}$ test was performed to determine if the number of alleles for the SNP were significantly different from the expectations of Hardy-Weinberg equilibrium (HWE). Logistic regression analysis, with adjustment for sex and/or smoking status using SPSS Binary Logistic Covariates, was used to determine the association between the genotypes and the risk of lung cancer by calculating the odds ratios (ORs) and $95 \%$ confidence intervals (CIs). $\mathrm{P}<0.05$ was considered to indicate a statistically significant difference.

\section{Results}

Characteristics of the study population. A total of 682 patients with lung cancer and 694 healthy subjects were recruited into the present study. The characteristics of the participants are listed in Table I. Among the 682 cases, 254 (37.3\%) patients were diagnosed with SCC, $226(33.1 \%)$ with AD and 202 (29.6\%) with SCLC. A similar number of patients received treatment (chemotherapy, $n=267$; radiotherapy, $n=269)$. The mean age was 58.96 years for patients and 58.54 years for the controls. The age of the participants was not statistically significantly different between the two groups $(\mathrm{P}=0.462)$. However, there were more smokers and males in the patient group compared with that in the control group (both $\mathrm{P}<0.001$ ). 
Table I. Characteristics of patients with lung cancer $(n=682)$ and heathy controls $(n=694)$.

\begin{tabular}{|c|c|c|c|}
\hline Characteristics & Patients & Controls & P-value \\
\hline Average age, years & 58.96 & 58.54 & $0.462^{\mathrm{a}}$ \\
\hline Sex, n (\%) & & & $<0.001^{\mathrm{b}}$ \\
\hline Male & $490(71.8)$ & $375(54.0)$ & \\
\hline Female & $192(28.2)$ & $319(46.0)$ & \\
\hline Smoking status, n (\%) & & & $<0.001^{b}$ \\
\hline Smoker & $398(58.4)$ & $106(15.3)$ & \\
\hline Never smoked & $284(41.6)$ & $588(84.7)$ & \\
\hline Histology, n (\%) & & & NA \\
\hline Squamous carcinoma & $254(37.3)$ & & \\
\hline Adenocarcinoma & $226(33.1)$ & & \\
\hline Small cell lung cancer & 202 (29.6) & & \\
\hline Chemotherapy, n (\%) & & & NA \\
\hline Yes & $267(39.1)$ & & \\
\hline No & $415(60.9)$ & & \\
\hline Radiotherapy, n (\%) & & & NA \\
\hline Yes & $269(39.4)$ & & \\
\hline No & $413(60.6)$ & & \\
\hline
\end{tabular}

${ }^{a}$ Analyzed using an unpaired Student's t-test. ${ }^{b}$ Analyzed using $\chi^{2}$ test. NA, not applicable.

Frequency of the BRCA1 rs799917 SNP. There were three BRCA1 rs799917 genotypes in the patients and healthy controls (wild-type homozygous $\mathrm{C} / \mathrm{C}$, mutant homozygous $\mathrm{T} / \mathrm{T}$ and mutant heterozygous $\mathrm{C} / \mathrm{T}$; Fig. S1). The genotypes between the cases and the controls were in accordance with HWE $\left(\chi^{2}=3.090 ; \mathrm{P}=0.078\right.$ and $\chi^{2}=0.194 ; \mathrm{P}=0.66$, respectively; Table II). The distribution frequencies of the BRCA1 rs799917 genotypes are presented in Table III. Logistic regression analysis showed that the genotype frequencies of $\mathrm{C} / \mathrm{C}$ vs. $\mathrm{C} / \mathrm{T}$ and $\mathrm{T} / \mathrm{T}$ in the cases were significantly different from that in the controls (OR, 0.745; $\mathrm{P}=0.011$ and $\mathrm{OR}, 0.699 ; \mathrm{P}=0.036$, respectively). As shown in Table I, sex was a significant factor.

In addition, BRCA may affect the mismatch repair complex by reducing its activity (23). Theoretically, toxicity derived from agents (such as tobacco), that promote double-strand DNA damage, emphasizes the role of BRCA in promoting DNA repair (24); therefore, a SNP may negatively influence BRCA. Thus, the differences remained statistically significant after adjusting for sex (OR, 0.730 and $\mathrm{P}=0.008$ for $\mathrm{C} / \mathrm{T}$; OR, 0.667 and $\mathrm{P}=0.020$ for $\mathrm{T} / \mathrm{T})$, smoking status $(\mathrm{OR}, 0.737$ and $\mathrm{P}=0.019$ for $\mathrm{C} / \mathrm{T}$; OR, 0.609 and $\mathrm{P}=0.010$ for $\mathrm{T} / \mathrm{T}$ ) or both $(\mathrm{OR}, 0.741$ and $\mathrm{P}=0.021$ for $\mathrm{C} / \mathrm{T}$; OR, 0.610 and $\mathrm{P}=0.011$ for $\mathrm{T} / \mathrm{T})$. The $\mathrm{C} / \mathrm{T}+\mathrm{T} / \mathrm{T}$ genotype group was associated with a lower risk of developing lung cancer compared with that in the $\mathrm{C} / \mathrm{C}$ genotype group (OR, 0.734; $\mathrm{P}=0.005)$. The differences were also significant after adjusting for sex $(\mathrm{OR}, 0.714 ; \mathrm{P}=0.002)$, smoking status (OR, 0.706; $\mathrm{P}=0.004)$ or both $(\mathrm{OR}, 0.709 ; \mathrm{P}=0.005)$. The results showed the T allele of the BRCA1 rs799917 SNP was associated with a lower risk of developing lung cancer and could be a protective factor against lung cancer.

The risk of developing lung cancer with the three genotypes for the BRCA1 rs799917 SNP was further evaluated
Table II. Hardy-Weinberg equilibrium.

\begin{tabular}{lccc}
\hline Groups & Number, $\mathrm{n}$ & $\chi^{2}$ & P-value $^{\mathrm{a}}$ \\
\hline Patients & 682 & 3.090 & 0.078 \\
Controls & 694 & 0.194 & 0.660 \\
\hline
\end{tabular}

${ }^{\mathrm{a}}$ Analyzed using the goodness-of-fit $\chi^{2}$ test.

based on stratification due to smoking status, pathological types and chemotherapy or radiotherapy for the patients with lung cancer (Table IV). In the stratified analyses for non-smokers, individuals with the $\mathrm{C} / \mathrm{T}$ or $\mathrm{T} / \mathrm{T}$ genotype had a lower risk of developing lung cancer compared with those with the $\mathrm{C} / \mathrm{C}$ genotype $(\mathrm{OR}, 0.681 ; \mathrm{P}=0.013$ and $\mathrm{OR}, 0.569$; $\mathrm{P}=0.021$, respectively). However, a significantly lower risk was not observed for smokers with either the $\mathrm{C} / \mathrm{T}$ or $\mathrm{T} / \mathrm{T}$ genotype compared with that in those that smoke with the $\mathrm{C} / \mathrm{C}$ genotype. When the BRCA1 rs799917 SNP was stratified based on pathological type, individuals with the T/T genotype still had a lower risk of developing lung cancer compared with those with the $\mathrm{C} / \mathrm{C}$ genotype in the SCC subgroup (OR, 0.454; $\mathrm{P}=0.007)$. In addition, those with the $\mathrm{C} / \mathrm{T}$ genotype appeared to have a lower risk of developing lung cancer compared with those with the $\mathrm{C} / \mathrm{C}$ genotype; however, the difference was not significant $(\mathrm{P}=0.055)$. Significant differences were not identified between the different genotypes among the other pathological subtypes. Individuals with either the $\mathrm{C} / \mathrm{T}$ or $\mathrm{T} / \mathrm{T}$ genotype had a lower risk of developing lung cancer compared with those with the $\mathrm{C} / \mathrm{C}$ genotype in the stratified analysis for those who did not 
Table III. Association between the BRCA1 rs799917 polymorphism and the risk of lung cancer.

\begin{tabular}{|c|c|c|c|c|c|c|c|c|c|c|}
\hline \multirow[b]{2}{*}{ Genotype } & \multirow[b]{2}{*}{$\begin{array}{c}\text { Patients, } \\
\text { n }(\%)\end{array}$} & \multirow[b]{2}{*}{$\begin{array}{l}\text { Controls, } \\
\mathrm{n}(\%)\end{array}$} & \multicolumn{2}{|c|}{ Lung cancer risk } & \multicolumn{2}{|c|}{$\begin{array}{l}\text { Adjusted lung } \\
\text { cancer risk for sex } \\
\text { and smoking status }\end{array}$} & \multicolumn{2}{|c|}{$\begin{array}{l}\text { Adjusted lung } \\
\text { cancer risk for sex }\end{array}$} & \multicolumn{2}{|c|}{$\begin{array}{c}\text { Adjusted } \\
\text { lung cancer risk } \\
\text { for smoking status }\end{array}$} \\
\hline & & & $\begin{array}{c}\text { OR } \\
(95 \% \mathrm{CI})\end{array}$ & P-value & $\begin{array}{c}\text { OR } \\
(95 \% \mathrm{CI})\end{array}$ & P-value & $\begin{array}{c}\text { OR } \\
(95 \% \mathrm{CI})\end{array}$ & P-value & $\begin{array}{c}\text { OR } \\
(95 \% \mathrm{CI})\end{array}$ & P-value \\
\hline $\mathrm{C} / \mathrm{C}$ & $\begin{array}{c}323 \\
(47.4)\end{array}$ & $\begin{array}{c}276 \\
(39.8)\end{array}$ & 1.0 (ref.) & & 1.0 (ref.) & & 1.0 (ref.) & & 1.0 (ref.) & \\
\hline $\mathrm{C} / \mathrm{T}$ & $\begin{array}{c}278 \\
(40.7)\end{array}$ & $\begin{array}{c}319 \\
(46.0)\end{array}$ & $\begin{array}{c}0.745 \\
(0.593-0.935)\end{array}$ & 0.011 & $\begin{array}{c}0.741 \\
(0.575-0.956)\end{array}$ & 0.021 & $\begin{array}{c}0.730 \\
(0.579-0.920)\end{array}$ & 0.008 & $\begin{array}{c}0.737 \\
(0.572-0.950)\end{array}$ & 0.019 \\
\hline $\mathrm{T} / \mathrm{T}$ & $\begin{array}{c}81 \\
(11.9)\end{array}$ & $\begin{array}{c}99 \\
(14.2)\end{array}$ & $\begin{array}{c}0.699 \\
(0.500-0.977)\end{array}$ & 0.036 & $\begin{array}{c}0.610 \\
(0.418-0.892)\end{array}$ & 0.011 & $\begin{array}{c}0.667 \\
(0.474-0.937)\end{array}$ & 0.020 & $\begin{array}{c}0.609 \\
(0.417-0.889)\end{array}$ & 0.010 \\
\hline $\mathrm{C} / \mathrm{T}+\mathrm{T} / \mathrm{T}$ & $\begin{array}{c}359 \\
(52.6)\end{array}$ & $\begin{array}{c}418 \\
(60.2)\end{array}$ & $\begin{array}{c}0.734 \\
(0.593-0.909)\end{array}$ & 0.005 & $\begin{array}{c}0.709 \\
(0.558-0.901)\end{array}$ & 0.005 & $\begin{array}{c}0.714 \\
(0.575-0.888)\end{array}$ & 0.002 & $\begin{array}{c}0.706 \\
(0.556-0.897)\end{array}$ & 0.004 \\
\hline
\end{tabular}

The data were analyzed using logistic regression. OR, odds ratio; CI, confidence interval.

Table IV. Stratified analyses of the BRCA1 rs799917 polymorphism and the risk of developing lung cancer.

\begin{tabular}{|c|c|c|c|c|c|c|c|}
\hline \multirow[b]{2}{*}{ Clinicopathological variables } & \multirow[b]{2}{*}{$\mathrm{C} / \mathrm{C}^{\mathrm{a}}$} & \multirow[b]{2}{*}{$\mathrm{C} / \mathrm{T}^{\mathrm{a}}$} & \multirow[b]{2}{*}{$\mathrm{T} / \mathrm{T}^{\mathrm{a}}$} & \multicolumn{2}{|c|}{$\begin{array}{c}\text { Lung } \\
\text { cancer risk, } \mathrm{C} / \mathrm{T} \text { vs. } \mathrm{C} / \mathrm{C}^{\mathrm{b}}\end{array}$} & \multicolumn{2}{|c|}{$\begin{array}{l}\text { Lung } \\
\text { cancer risk, } \mathrm{T} / \mathrm{T} \text { vs. } \mathrm{C} / \mathrm{C}^{\mathrm{c}}\end{array}$} \\
\hline & & & & OR $(95 \% \mathrm{CI})$ & P-value & OR $(95 \% \mathrm{CI})$ & P-value \\
\hline \multicolumn{8}{|l|}{ Smoking status } \\
\hline Smoker & $181 / 44$ & $164 / 44$ & $53 / 18$ & $0.907(0.568-1.450)$ & 0.684 & $0.718(0.383-1.345)$ & 0.300 \\
\hline Non-smoker & $142 / 232$ & $114 / 275$ & $28 / 81$ & $0.681(0.503-0.922)$ & 0.013 & $0.569(0.353-0.918)$ & 0.021 \\
\hline \multicolumn{8}{|l|}{ Pathological type } \\
\hline Squamous carcinoma & $125 / 276$ & $105 / 319$ & $24 / 99$ & $0.704(0.492-1.008)$ & 0.055 & $0.454(0.257-0.803)$ & 0.007 \\
\hline Adenocarcinoma & $104 / 276$ & $91 / 319$ & $31 / 99$ & $0.811(0.577-1.141)$ & 0.229 & $0.800(0.492-1.303)$ & 0.371 \\
\hline Small cell lung cancer & $94 / 276$ & $82 / 319$ & $26 / 99$ & $0.764(0.524-1.116)$ & 0.164 & $0.641(0.369-1.112)$ & 0.113 \\
\hline \multicolumn{8}{|l|}{ Chemotherapy } \\
\hline Yes & $119 / 276$ & $109 / 319$ & $39 / 99$ & $0.816(0.584-1.141)$ & 0.235 & $0.847(0.528-1.357)$ & 0.489 \\
\hline No & $204 / 276$ & $169 / 319$ & $42 / 99$ & $0.721(0.527-0.968)$ & 0.030 & $0.485(0.306-0.767)$ & 0.002 \\
\hline \multicolumn{8}{|l|}{ Radiotherapy } \\
\hline Yes & $120 / 276$ & $119 / 319$ & $30 / 99$ & $0.921(0.659-1.286)$ & 0.628 & $0.652(0.390-1.087)$ & 0.101 \\
\hline No & 203/276 & $159 / 319$ & $51 / 99$ & $0.659(0.490-0.884)$ & 0.005 & $0.599(0.388-0.923)$ & 0.020 \\
\hline
\end{tabular}

The data were analyzed using logistic regression and results were adjusted for sex or sex and smoking status. ${ }^{\mathrm{a}}$ Number of patients/number of controls. ${ }^{b}$ Adjusted for sex. ${ }^{c}$ Adjusted for sex and smoking status.

receive chemotherapy $(\mathrm{OR}, 0.721$ and $\mathrm{P}=0.030$ for $\mathrm{C} / \mathrm{T}$; $\mathrm{OR}$, 0.485 and $\mathrm{P}=0.002$ for $\mathrm{T} / \mathrm{T})$ or radiotherapy treatment $(\mathrm{OR}$, 0.659 and $\mathrm{P}=0.005$ for $\mathrm{C} / \mathrm{T}$; $\mathrm{OR}, 0.599$ and $\mathrm{P}=0.020$ for $\mathrm{T} / \mathrm{T}$ ). However, significant differences were not observed in those that did receive chemotherapy or radiotherapy treatment among the different genotypes.

\section{Discussion}

Lung cancer is globally the leading cause of cancer death, particularly in men (25). The incidence rate and developing trend vary significantly based on sex, age, race or ethnicity, socioeconomic status and geographical location, depending on the history of smoking in the individual (25). In a survey, the increase in the incidence rate of lung cancer was shown to rise equally with smoking dose in a clear dose-response relationship (25). Typically, it increased the risk of developing lung cancer by 5 to 10 -fold (25). Exposure to an environment filled with tobacco smoke also increases the risk of developing lung cancer among non-smokers by $\sim 20 \%$ (25). In the present study, there were more males and smokers in the case group than in the control group. 
BRCA1 is a tumor suppressor gene located on chromosome 17q21, that contains 24 exons and encodes a functional macromolecule protein, containing 1,863 amino acids (26). In numerous studies $(5,27,28)$, BRCA1 was shown to participate in several important biological functions, including the cell cycle, apoptosis, gene and protein stability, centrosome replication, DNA damage repair and transcriptional regulation. Furthermore, BRCA1 can affect tumor development, cell migration and response to chemoradiotherapy $(5,27,28)$. DNA damage repair includes homologous recombination repair (HRR), non-homologous end-joining (NHEJ), nucleotide excision repair (NER), base excision repair (BER) and mismatch repair (MMR) (29). In previous studies, BRCA1 was shown to play a significant role in HRR, NHEJ and NER $(30,31)$.

The BRCA1 rs799917 SNP leads to an amino acid change from proline to leucine at position 871 in the BRCA1 protein (32). This mutation may cause a corresponding change in its physiological function; however, the mechanism is unclear. Nicoloso et al (18) found that microRNA(miR)-638 could negatively regulate $\mathrm{mRNA}$ and protein BRCA1 expression in breast cancer cells and might target the coding sequence (CDS), but not a conserved target site inside the 3'-untranslated region. After miR-638 overexpression, cells expressing the $\mathrm{C} / \mathrm{C}$ genotype displayed a stronger reduction of BRCA1 protein levels. In addition, the rs799917 T>C SNP located in the BRCA1 CDS could affect the interaction between BRCA1 mRNA and miR-638. The rs799917 $\mathrm{T}$ allele was associated with a weaker miR-638-dependent BRCA1 reduction (18). Hypothetically, individuals with the rs799917 $\mathrm{T}$ allele express higher mRNA and protein BRCA1 levels compared with those carrying the $\mathrm{C}$ allele. In other words, the $\mathrm{T}$ allele might indirectly play a protective role in the development of breast cancer. This observation has been validated in human bronchial epithelial cells using chemical carcinogens to induce cell transformation (33), highlighting the essential involvement of both miR-638 and BRCA1 in the tumorigenesis of epithelial cells.

Sirisena et al (34) found the G allele of rs799917 SNP ( $\beta,-1.069$; standard error, $0.537 ; \mathrm{P}=0.047)$ was associated with age of onset, between 50 and 59 years in patients with sporadic breast cancer from Sri Lanka. In previous studies, the BRCA1 rs799917 SNP was not significantly associated with breast cancer risk (35-38); however, the results have not been consistent. Previous research investigating rs799917 has involved multiple tumors. Zhou et al (39) showed that individuals with the T/T genotype had a significantly decreased risk of developing cervical cancer compared with those with the $\mathrm{C} / \mathrm{T}$ and $\mathrm{C} / \mathrm{C}$ genotypes. In addition, Chang et al (32) investigated the rs799917 SNP with glioblastoma multiforme susceptibility in American Caucasians and found that individuals with the T/T genotype had a reduced risk of developing glioblastoma compared with that in individuals with the $\mathrm{C} / \mathrm{C}$ genotype. Furthermore, Zhang et al (40) found that the risk of developing esophageal SCC (ESCC) was significantly increased in carriers of the $\mathrm{C} / \mathrm{T}$ or $\mathrm{C} / \mathrm{C}$ genotype compared with that in those with the $\mathrm{T} / \mathrm{T}$ genotype, in the Chinese population. Lee et al (41) investigated the association between the BRCA1 rs799917 SNP and clinical outcomes in patients with non-small cell lung cancer treated with first-line paclitaxel-cisplatin chemotherapy and found that patients carrying the $\mathrm{T}$ allele had a significantly improved chemotherapeutic response and overall survival time. Furthermore, individuals with the rs799917 T/T genotype had a significantly decreased risk of developing gastric cancer compared with those with the $\mathrm{C} / \mathrm{T}$ and $\mathrm{C} / \mathrm{C}$ genotypes, in a Chinese Han population (42). Xu et al (43) showed the rs799917 T/T genotype could decrease the risk of developing cervical cancer, ESCC, gastric cancer and non-Hodgkin lymphoma among Asian populations in one or more genetic models. Taken together, the results of these studies indicated that the BRCA1 rs799917 SNP, particularly the T allele, could serve as a potential clinical biomarker in patients with cancer.

In the present study, the association between the BRCA1 rs799917 SNP and susceptibility to lung cancer was examined in patients with lung cancer in the Han Chinese population from Liaoning Province (China). The data showed the $\mathrm{T}$ allele was associated with a lower risk of developing lung cancer and could be a protective factor against this disease. However, there were limitations to the current study. It is important to validate the results using a larger sample size, and to confirm the result in the Han Chinese population from different geographical regions and in other ethnic groups. In addition, it is important to identify and understand the mechanism by which the rs799917 SNP affects the mRNA and protein BRCA1 expression levels in lung cancer. Therefore, in future experiments, multiple SNPs will be selected (including BRCA1 rs799917) to investigate their association with lung cancer, and MMR protein activity would also be determined by comparing healthy donors and patients with lung cancer to verify the association between SNPs and the development of tumors.

\section{Acknowledgements}

Not applicable.

\section{Funding}

This study was supported by funding from the Clinical Capability Construction Project for Liaoning Provincial Hospitals (grant no. LNCCC-B08-2014).

\section{Availability of data and materials}

The datasets used and/or analyzed during the current study are available from the corresponding author on reasonable request.

\section{Authors' contributions}

DL, YG, BZ, YY and YZ made substantial contributions to conception and design of the study. HC, LB and YQ made substantial contributions to acquisition of data. DL, YG, LL, $\mathrm{HC}$, YY and YZ were involved in drafting the manuscript. DL and LL contributed to analysis and interpretation of data, and were involved in revising the manuscript critically for important intellectual content. DL, YG, YY and YZ agreed to be accountable for all aspects of the work in ensuring that questions related to the accuracy or integrity of any part of the work are appropriately investigated and resolved. All authors have given final approval of the version to be published. 


\section{Ethics approval and consent to participate}

All individual participants voluntarily joined the study and provided written informed consent. The Ethics Committee of the China Medical University (Shenyang, China) approved the investigation.

\section{Patient consent for publication}

Not applicable.

\section{Competing interests}

The authors declare that they have no competing interests.

\section{References}

1. Wild CP, Weiderpass E and Stewart BW (eds): World Cancer Report: Cancer research for cancer prevention. Lyon, France, International Agency for Research on Cancer, 2020.

2. Jemal A, Bray F, Center MM, Ferlay J, Ward E and Forman D: Global cancer statistics. CA Cancer J Clin 61: 69-90, 2011.

3. Alberg AJ, Ford JG and Samet JM; American College of Chest Physicians: Epidemiology of lung cancer: ACCP evidence-based clinical practice guidelines (2nd edition). Chest 132 (Suppl 3): 29S-55S, 2007.

4. Tiseo M, Bordi P, Bortesi B, Boni L, Boni C, Baldini E, Grossi F, Recchia F, Zanelli F, Fontanini G, et al: ERCC1/BRCA1 expression and gene polymorphisms as prognostic and predictive factors in advanced NSCLC treated with or without cisplatin. $\mathrm{Br}$ J Cancer 108: 1695-1703, 2013.

5. Sallum LF, Andrade L, Bastos Eloy da Costa L, Ramalho S, Ferracini AC, Natal RA, Brito ABC, Sarian LO and Derchain S: BRCA1, Ki67, and $\beta$-catenin immunoexpression is not related to differentiation, platinum response, or prognosis in women with low- and high-grade serous ovarian carcinoma. Int J Gynecol Cancer 28: 437-447, 2018.

6. Huyton T, Bates PA, Zhang X, Sternberg MJ and Freemont PS: The BRCA1 C-terminal domain: Structure and function. Mutat Res 460: 319-332, 2000.

7. Fairley S, Lowy-Gallego E, Perry E and Flicek P: The international genome sample resource (IGSR) collection of open human genomic variation resources. Nucleic Acids Res 48 (D1): D941-D947, 2020.

8. NCBI. Gene Database. RefSeq, 2020. Available at https://www. ncbi.nlm.nih.gov/gene/672.

9. Morris JR, Pangon L, Boutell C, Katagiri T, Keep NH and Solomon E: Genetic analysis of BRCA1 ubiquitin ligase activity and its relationship to breast cancer susceptibility. Hum Mo Genet 15: 599-606, 2006.

10. Moynahan ME and Jasin M: Mitotic homologous recombination maintains genomic stability and suppresses tumorigenesis. Nat Rev Mol Cell Biol 11: 196-207, 2010.

11. Miki Y, Swensen J, Shattuck-Eidens D, Futreal PA, Harshman K, Tavtigian S, Liu Q, Cochran C, Bennett LM, Ding W, et al: A strong candidate for the breast and ovarian cancer susceptibility gene BRCA1. Science 266: 66-71, 1994.

12. Ho MM, Ng AV, Lam S and Hung JY: Side population in human lung cancer cell lines and tumors is enriched with stem-like cancer cells. Cancer Res 67: 4827-4833, 2007.

13. Clark SL, Rodriguez AM, Snyder RR, Hankins GD and Boehning D: Structure-function of the tumor suppressor BRCA1. Comput Struct Biotechnol J 1: e201204005, 2012.

14. Medema RH and Macůrek L: Checkpoint control and cancer. Oncogene 31: 2601-2613, 2012

15. Symington LS and Gautier J: Double-strand break end resection and repair pathway choice. Annu Rev Genet 45: 247-271, 2011.

16. Scully R and Livingston DM: In search of the tumour-suppressor functions of BRCA1 and BRCA2. Nature 408: 429-432, 2000.

17. Venkitaraman AR: Cancer susceptibility and the functions of BRCA1 and BRCA2. Cell 108: 171-182, 2002.

18. Nicoloso MS, Sun H, Spizzo R, Kim H, Wickramasinghe P, Shimizu M, Wojcik SE, Ferdin J, Kunej T, Xiao L, et al: Single-nucleotide polymorphisms inside microRNA target sites influence tumor susceptibility. Cancer Res 70: 2789-2798, 2010.
19. Detterbeck FC, Boffa DJ, Kim AW and Tanoue LT: The eighth edition lung cancer stage classification. Chest 151: 193-203, 2017.

20. World Health Organization: Guidelines for controlling and monitoring the tobacco epidemic. Geneva, Switzerland, WHO, 1998.

21. Wang HT, Gao Y, Zhao YX, Yu H, Wang TL, Bai L, Chen YZ, Zhang HB, Zhou BS, Qu YL, et al: PARP-1 rs3219073 polymorphism may contribute to susceptibility to lung cancer. Genet Test Mol Biomarkers 18: 736-740, 2014

22. Livak KJ and Schmittgen TD: Analysis of relative gene expression data using real-time quantitative PCR and the 2(-Delta Delta C(T)) method. Methods 25: 402-408, 2001

23. Yurgelun MB, Kulke MH, Fuchs CS, Allen BA, Uno H, Hornick JL, Ukaegbu CI, Brais LK, McNamara PG, Mayer RJ, et al: Cancer susceptibility gene mutations in individuals with colorectal cancer. J Clin Oncol 35: 1086-1095, 2017.

24. Grynberg M, Raad J, Comtet M, Vinolas C, Cédrin-Durnerin I and Sonigo C: Fertility preservation in BRCA-mutated women: When and how? Future Oncol 14: 483-490, 2018.

25. Torre LA, Siegel RL and Jemal A: Lung cancer statistics. Adv Exp Med Biol 893: 1-19, 2016.

26. Kennedy RD, Quinn JE, Johnston PG and Harkin DP: BRCA1: Mechanisms of inactivation and implications for management of patients. Lancet 360: 1007-1014, 2002.

27. Qiang L, Yang Y, Ma YJ, Chen FH, Zhang LB, Liu W, Qi Q, $\mathrm{Lu} \mathrm{N}$, Tao L, Wang XT, et al: Isolation and characterization of cancer stem like cells in human glioblastoma cell lines. Cancer Lett 279: 13-21, 2009.

28. $\mathrm{Wu} \mathrm{J}, \mathrm{Lu} \mathrm{LY}$ and $\mathrm{Yu} \mathrm{X}$ : The role of BRCA1 in DNA damage response. Protein Cell 1: 117-123, 2010.

29. Chatterjee $\mathrm{N}$ and Walker GC: Mechanisms of DNA damage, repair, and mutagenesis. Environ Mol Mutagen 58: 235-263, 2017.

30. Moynahan ME, Cui TY and Jasin M: Homology-directed dna repair, mitomycin-c resistance, and chromosome stability is restored with correction of a Brcal mutation. Cancer Res 61: 4842-4850, 2001

31. Wu HC, Delgado-Cruzata L, Machella N, Wang Q, Santella RM and Terry MB: DNA double-strand break repair genotype and phenotype and breast cancer risk within sisters from the New York site of the breast cancer family registry (BCFR). Cancer Causes Control 24: 2157-2168, 2013

32. Chang JS, Yeh RF, Wiencke JK, Wiemels JL, Smirnov I, Pico AR, Tihan T, Patoka J, Miike R, Sison JD, et al: Pathway analysis of single-nucleotide polymorphisms potentially associated with glioblastoma multiforme susceptibility using random forests. Cancer Epidemiol Biomarkers Prev 17: 1368-1373, 2008.

33. Li D, Wang Q, Liu C, Duan H, Zeng X, Zhang B, Li X, Zhao J, Tang S, Li Z, et al: Aberrant expression of miR-638 contributes to benzo(a)pyrene-induced human cell transformation. Toxicol Sci 125: 382-391, 2012.

34. Sirisena ND, Adeyemo A, Kuruppu AI, Samaranayake N and Dissanayake VHW: Genetic variants associated with clinicopathological profiles in sporadic breast cancer in Sri Lankan women. J Breast Cancer 21: 165-172, 2018.

35. Yang M, Du X, Zhang F and Yuan S: Association between BRCA1 polymorphisms rs799917 and rs1799966 and breast cancer risk: A meta-analysis. J Int Med Res 47: 1409-1416, 2019.

36. Ghafouri-Fard S, Dianatpour A and Faramarzi S: Meta-analysis of BRCA1 polymorphisms and breast cancer susceptibility. Klin Onkol 31: 330-338, 2018

37. Ma J, Liu M, Zhang X and BuRi G: Correlation anslysis of sporadic breast cancer and BRCA1 gene plymorphisms in the Han nationality and the Mongol nationality of inner Mongolia region. Zhonghua Yi Xue Za Zhi 95: 3746-3749, 2015 (In Chinese).

38. Qin TT, Chen T, Zhang Q, Du HN, Shu YQ, Luo K and Zhu LJ: Association between BRCA1 rs799917 polymorphism and breast cancer risk: A meta-analysis of 19,878 subjects. Biomed Pharmacother 68: 905-910, 2014.

39. Zhou X, Han S, Wang S, Chen X, Dong J, Shi X, Xia Y, Wang X, $\mathrm{Hu} \mathrm{Z}$ and Shen H: Polymorphisms in HPV E6/E7 protein interacted genes and risk of cervical cancer in Chinese women: A case-control analysis. Gynecol Oncol 114: 327-331, 2009.

40. Zhang X, Wei J, Zhou L, Zhou C, Shi J, Yuan Q, Yang M and Lin D: A functional BRCA1 coding sequence genetic variant contributes to risk of esophageal squamous cell carcinoma. Carcinogenesis 34: 2309-2313, 2013. 
41. Lee SY, Kang HG, Yoo SS, Kang YR, Choi YY, Lee WK, Choi JE, Jeon HS, Shin KM, Oh IJ, et al: Polymorphisms in DNA repair and apoptosis-related genes and clinical outcomes of patients with non-small cell lung cancer treated with first-line paclitaxel-cisplatin chemotherapy. Lung Cancer 82: 330-339, 2013.
42. Wang K, Xu L, Pan L, Xu K and Li G: The functional BRCA1 rs799917 genetic polymorphism is associated with gastric cancer risk in a Chinese Han population. Tumour Biol 36: 393-397, 2015.

43. Xu GP, Zhao Q, Wang D, Xie WY, Zhang LJ, Zhou H, Chen SZ and Wu LF: The association between BRCA1 gene polymorphism and cancer risk: A meta-analysis. Oncotarget 9: 8681-8694, 2018. 